\title{
Agronomic characterization variety Quebranta in the Ica region, Peru
}

\author{
Hanna Cáceres Yparraguirre ${ }^{a}$ and Patricia Quispe Egocheaga \\ Area of Research, Development Agroindustrial Technology Innovation Center, Panamericana Sur km 293.3 Salas \\ Guadalupe Ica, Peru
}

\begin{abstract}
The study was to identify the best strains of the Quebranta variety cultivated in Peruvian region of Ica during campaigns 2011 to 2014. The evaluations were conducted in fourteen vineyards and the criteria to evaluate each one of them was that the same owner vineyard, would identify the best strain Quebranta for their good performance and sanitary quality. Productive parameters as grape weight and number of bunches per vine, average cluster weight, length and width of cluster and Berry weight were evaluated. Within the parameters of vegetative growth was assessed Ravaz index and as parameter for the composition of the grape was evaluated the concentration soluble solids ( ${ }^{\circ} \mathrm{Brix}$ ), total acidity and $\mathrm{pH}$. Four phenological stages were recorded and defined from observed events in the branch of the year: Phase I comprising bud of winter to sprouting; Phase II of sprouting to full bloom; Phase III of full bloom to veraison and Phase IV of veraison to maturity. At the time of fruit setting were taken leaf samples to assess the State of health of each strain to Grapevine fanleaf virus, Grapevine fleck virus, Grapevine leafroll virus 1, Grapevine leafroll virus 3 and Tomato ringspot virus. The variables average bunch weight (22\%), berry weight (20\%), bunch length (13\%) and bunch width (11\%) presented the lowest values coefficient of variation. The variables of weight of grape per vine (52\%), number of bunch (42\%) and index of Ravaz $(60 \%)$ has the highest values of coefficient of variation. Four variables were used that showed lower values $(25 \%)$ coefficient of variation for the weighted average. The variables that presented perfect correlation were berry weight and width of bunch, berry weight and Ravaz index, length of bunch and Ravaz index. The analysis of conglomerate allowed to group the strains in study in two groups which showed a significant difference between them $(p<0.0001)$. The principal component analysis identified that the variable of weight per bunch, index Ravaz and berry weight distinguished the 77 strains studied. Soluble solids, acidity and $\mathrm{pH}$ of the grapes from the fourteen vineyards present significant difference. The phenology of the 77 study strains does not present significant difference. Samples of tender leaves were used for virus scanning. Only the variables of length and width of bunch showed a coefficient of variation acceptable accuracy. The weighted average analysis allowed choosing the best strains which are: QT1; QT5; QCH2; QCH3; QYJ1; QT2; QT3; QYJ4; QT4; QCH1 which will serve as base material for future certifications and improvement of this variety. The variables such as the number of bunch and bunch width feature the highest perfect correlation $(0.89 \%)$. The grape presented in average $24.67^{\circ}$ Brix, acidity $4.14 \mathrm{~g} / \mathrm{L}$ tartaric acid and 3.92 of $\mathrm{pH}$. The phenological period total average of the 77 strains was 202 days and shows no significant difference. The results of the analysis of virus were negative for the 77 strains and for the five viruses that were analyzed.
\end{abstract}

\section{Introduction}

There are 6154 varieties of vine, in 35 states, between members and non-members of the International Organization of Vine and Wine [1]. In spite of this enormous diversity, only a small number of these have commercial importance.

Our country was the first in South America in cultivating vineyards and also to produce wines [2]. In the Peru between 1532 and 1580 were founded more than 700 population centers. On the coast, characterized by it is aridity was adapted in a surprising way [3]. The Inca Garcilaso de la Vega, in their Real-world feedback, is the only one that speaks clearly about the introduction of the grapevine.

The grape was introduced the Prieta, variety of red ink, black and clear quality of a very particular. It was the only one that was until the early eighteenth century and this it was derived numerous clones as the Quebranta grape. The origin of the varieties of wider dissemination in the

a Corresponding author: hcaceres@citeagroindustrial.com.pe country that could be considered as native or creole by its antiquity would correspond to subsequent imports; this would be the case of the Muscatel inks, Black (Tintilla) and Mollar, or the white as the Albilla and Italy [2]. At present there are eight varieties called pisco grapes (Quebranta, Uvina, Negra criolla, Mollar, Albilla, Italy, Muscatel and Torontel), of which the Pisco is elaborated, a grape brandy, colorless considered as the drink flag of Peru and its Appellation of Origin includes the departments of Lima, Ica, Arequipa, Moquegua and Tacna [4]. History tells us that the epicenter and where it is established widely the viticulture is the Valley of Ica, where he founded the city of Valverde in 1563 [5] and continues to enjoy this feature to occupy $55 \%$ of national production [6]. The traditional variety and more important in the province of Ica is the Quebranta, object of study in the present work. Is red and black, pleasant-tasting, considered non aromatic, tolerant to phylloxera. It is the result of natural hybridization of Negra criolla with the Mollar [7].

It is possible that although some vineyards are separated a few kilometers, different areas have their dominant 
cultivars, fruit of their differences of soil and microclimate [8]. There are few studies of agronomic characterization of the vine in Peru that relates their results with the plant material to spread and future breeding programs. In Ica, the references are based on improving the production and morphological characterization. As a result, there are no commercial nurseries in the material to meet the demand of the new plantations and replants that need certified plants free of viruses and other diseases. The improvement of the propagation material generates: increased vegetative growth of the grapevines, greater longevity of the plants, greater uniformity in the vineyards, greater performance and productive potential in time, better quality of the grapes, greater content of sugar, uniform maturity, best curdle, and uniformity of the caliber of the berries [9]. In spite of the importance of the Quebranta and its derivative the Pisco, there are no studies that treat on the characterization of the plant material. In this sense, the present study aims to obtain propagation material for being able to choose the best strains of each plot of Quebranta representative in the study area, covering a need for future plantations with healthy plant material and agronomic qualities of good.

\section{Material and methods}

\subsection{Study area}

Grape vines (Vitis vinífera) variety Quebranta (Fig. 1), were selected and coded 2011 in eight districts (fourteen vineyards) in the province of Ica (Pueblo Nuevo, Cercado de Ica, San Juan Bautista, Subtanjalla, Pachacutec; Salas Guadalupe, Santiago) (Table 1). Ica is located in the central coast of Peru. Its climate is typically arid. The daily solar radiation has an average value of 7 hours; the average temperature is $21^{\circ} \mathrm{C}$ with an average maximum of $29^{\circ} \mathrm{C}$ and an average minimum of $14^{\circ} \mathrm{C}$. As the annual rainfall is nearly zero, the vineyards are irrigated in its majority by flooding during rainy periods (January-March) and in the dry season (April-November) with groundwater.

\subsection{Plant material}

This work has been started in the year 2011 and its application arrived until 2014. The criterion that was used to mark was that the owners themselves identify as the variety mentioned, that this good performance and the absence of

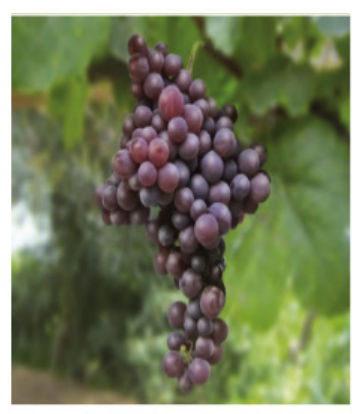

Figure 1. Quebranta Pisco grape cluster. external symptoms of pests and diseases. The conduction system was generally in "Galera from Ica" or modifications of this by each owner of the vineyard. The pruning system that used consisted of leave thumbs of the replacement of two to three buds. The plants should have more than 15 years of sown.

\subsection{Agronomic characterization}

To determine the agronomic performance of each of the strains of Quebranta, three parameters were measured.

1. Productive parameters: when the plants reached the optimum ripening ( $24{ }^{\circ}$ Brix for Pisco) (March), harvested all bunches, cutting flush at tendril and depositing in properly labeled crates.

2. For each of the strains weight of grapes (g), number of bunches, bunches weight average $(\mathrm{g})$, average weight of 100 berries $(\mathrm{g})$, length and average width of bunches $(\mathrm{mm})$ were measured.

3. Parameters of vegetative development: the Ravaz index assessed the balance between vegetation and production of a vineyard. It is estimated, for a harvest, dividing the kilograms of grapes (a result of the harvest) (March) between the kilograms of branches collected (result of the pruning) (August) [8].

4. Parameters for the composition of the grape: when the plants reached the of optimum ripeness, the grapes were harvested; these are squeezed and obtained which juice be assessed ${ }^{\circ}$ Brix, total acidity and $\mathrm{pH}$ [8].

5. The phonological period four phonological stages was evaluated and defined from events observed in the branch of the year: Phase I is from pruning to sprouting; phase II is sprouting to full flowering; phase III is in full flowering to veraison and phase IV is veraison to harvest or ripening.

6. It was also evaluated the health connection to the virus, in the Virus Laboratory at the National Service of Agrarian Health of Peru, located in the city of Lima, the test was conducted DAS-ELISA (Double Antibody Sandwich-Enzyme Linked Immuno sorbent Assay) to assess the health status of the strains regarding on the following viruses: Grapevine fanleaf virus, Grapevine fleck virus, Grapevine leafroll virus 1, Grapevine leafroll virus 3 and Tomato ringspot virus. The samples analyzed were a mix of tender and almost mature leaves collected in time flowering.

\subsection{Statistical analysis}

The data from the agronomic characterization were analyzed by means of INFOSTAD/Professional version 2013 program. The mean, standard deviation, variance, standard error, the coefficient of variation, minimum and maximum value were used to have an overview on the variability of the quantitative characteristics of the strains under study.

Performed was a weighted average to determine the best allocation of the 77 strains, considering the variables with less variability. An analysis of variance was performed multivariate analyzes to determine the significant difference in the composition of the 77 strains under study. We performed a multivariate analysis using the 
Table 1. Descriptive geographical origin of 77 strains of Quebranta province of Ica, 2011-2014.

\begin{tabular}{|c|c|c|c|}
\hline \multirow{2}{*}{$\begin{array}{l}\text { Geographical origin } \\
\text { (District/sector) }\end{array}$} & \multicolumn{2}{|c|}{ Coordinates } & \multirow[t]{2}{*}{ Code of strains } \\
\hline & Latitude & Length & \\
\hline Guadalupe/Huaranga & $13^{\circ} 59^{\prime} 12.9300^{\prime \prime} \mathrm{S}$ & $75^{\circ} 45^{\prime} 29.9580^{\prime \prime} \mathrm{W}$ & $\begin{array}{l}\text { QL1-QL2-QL3-QL4-QL5- } \\
\text { QL6-QL7-QL8 }\end{array}$ \\
\hline Guadalupe/Los pobres & $13^{\circ} 59^{\prime} 61.6000^{\prime \prime} \mathrm{S}$ & $75^{\circ} 46^{\prime} 12.3719^{\prime \prime} \mathrm{W}$ & $\begin{array}{l}\text { QCV1-QCV2-QCV3-QCV4- } \\
\text { QCV5 } \\
\text { QCV6-QCV7-QCV8-QCV9- } \\
\text { QCV10 }\end{array}$ \\
\hline SanJuanBautista/Quilloay & $14^{\circ} 00^{\prime} 46.5060^{\prime \prime} \mathrm{S}$ & $75^{\circ} 44^{\prime} 41.3100^{\prime \prime} \mathrm{W}$ & $\begin{array}{l}\text { QST1-QST2-QST3-QST4- } \\
\text { QST5 }\end{array}$ \\
\hline SanJuanBautista/Longar & $14^{\circ} 00^{\prime} 11.7059^{\prime \prime} \mathrm{S}$ & $75^{\circ} 44^{\prime} 23.3279^{\prime \prime} \mathrm{W}$ & QR1-QR2-QR3-QR4-QR5 \\
\hline $\begin{array}{l}\text { SanJuanBautista/Tres } \\
\text { generaciones }\end{array}$ & $14^{\circ} 00^{\prime} 35.3580^{\prime \prime} \mathrm{S}$ & $75^{\circ} 45^{\prime} 15.1920^{\prime \prime} \mathrm{W}$ & QT1-QT2-QT3-QT4-QT5 \\
\hline SanJuanBautista/Yanquiza & $14^{\circ} 01^{\prime} 24.8999^{\prime \prime} \mathrm{S}$ & $75^{\circ} 44^{\prime} 24.8399^{\prime \prime} \mathrm{W}$ & QY1-QY2-QY3-QY4-QY5 \\
\hline Subtanjalla/Macacona & $14^{\circ} 01^{\prime} 50.9999^{\prime \prime} \mathrm{S}$ & $75^{\circ} 46^{\prime} 05.4479^{\prime \prime} \mathrm{W}$ & QG1-QG2-QG3-QG4-QG5 \\
\hline CercadodeIca/Cachiche & $14^{\circ} 05^{\prime} 50.3459^{\prime \prime} \mathrm{S}$ & $75^{\circ} 43^{\prime} 51.6359^{\prime \prime} \mathrm{W}$ & $\begin{array}{l}\text { QCH1-QCH2-QCH3-QCH4- } \\
\text { QCH5 }\end{array}$ \\
\hline PuebloNuevo/Puno & $14^{\circ} 08^{\prime} 52.0440^{\prime \prime} \mathrm{S}$ & $75^{\circ} 42^{\prime} 16.7580^{\prime \prime} \mathrm{W}$ & $\begin{array}{l}\text { QQ1-QQ2-QQ3-QQ3-QQ4- } \\
\text { QQ5 }\end{array}$ \\
\hline PuebloNuevo/Conuca & $14^{\circ} 07^{\prime} 21.5399^{\prime \prime} \mathrm{S}$ & $75^{\circ} 42^{\prime} 08.3640^{\prime \prime} \mathrm{W}$ & QC1-QC2-QC3-QC4-QC5 \\
\hline PuebloNuevo/YajasiM & $14^{\circ} 08^{\prime} 22.3019^{\prime \prime} \mathrm{S}$ & $75^{\circ} 41^{\prime} 43.7999^{\prime \prime} \mathrm{W}$ & QM1-QM2-QM3-QM4 \\
\hline PuebloNuevo/YajasiLC & $14^{\circ} 08^{\prime} 02.7120^{\prime \prime} \mathrm{S}$ & $75^{\circ} 41^{\prime} 30.3419^{\prime \prime} \mathrm{W}$ & $\begin{array}{l}\text { QYJ1-QYJ2-QYJ3-QYJ4- } \\
\text { QYJ5 }\end{array}$ \\
\hline Pachacutec/SanAntonio & $14^{\circ} 09^{\prime} 46.6680^{\prime \prime} \mathrm{S}$ & $75^{\circ} 40^{\prime} 50.3280^{\prime \prime} \mathrm{W}$ & $\begin{array}{l}\text { QSA1-QSA2-QSA3-QSA4- } \\
\text { QSA5 }\end{array}$ \\
\hline Santiago/HuarangoMocho & $14^{\circ} 11^{\prime} 04.4699^{\prime \prime} \mathrm{S}$ & $75^{\circ} 41^{\prime} 32.5799^{\prime \prime} \mathrm{W}$ & QH1-QH2-QH3-QH4-QH5 \\
\hline
\end{tabular}

hierarchical cluster analysis using the algorithm of Ward and the Euclidean distance squared, to group the 77 strains of the variety Quebranta in groups with agronomic characteristics of maximum similarity with respect to the variables studied. The principal components analysis was used to identify the quantitative variables that have more weight to differentiate the 77 strains of Quebranta. With a graphic Biplot was observed the relationship between variables and accessions.

The canonical discriminate analysis was used to determine the quantitative features that discriminate against varieties defined a priori.

\section{Results}

The descriptive statistics relevant to the studied variables are described in Table 2.

To evaluate the weighted average is took four variables and allocated the weight according to importance in the performance of the crop. It was not considered the weight of grapes per plant, number of clusters per plant and Ravaz index, due to the high variability that presented.

Average bunch weight $(35 \%)+$ average weight of 100 berries $(35 \%)+$ Length of bunch $(15 \%)+$ Width of bunch $(15 \%)$. From the results shown in Table 3, we can see the 20 best strains.
From the results shown in Table 4 we can see that there is significant difference in the composition of the grapes from some vineyards. The average total phenological period of the 77 strains was 202 days and shows no significant difference $(p>0.05)$. The result of the analysis of virus was negative for the 77 strains and for the five viruses that were analyzed (Table 5).

To find the conglomerate analysis was used all the quantitative agronomic characteristics (total weight and number of bunch per vine, bunch weight, berry weight, length and width of bunch and Ravaz index). The structure obtained by the method of hierarchical clustering of Ward and the Euclidean distance squared, is represented by means of a dendogram in Fig. 2. Two groups were identified at a distance of 135.85. In the Table 6 shows the multivariate analysis of variance to the two groups and sub groups generated from group 2, where it was noted that there was a significant difference for all.

In Figure 3 shows that the variable weight of grapes per vine has a greater association with the grapes from Yajasi LC, the variable weight of berry has a greater association with the grapes from Macacona. The grape coming from Yanquiza and The Pobres was not significant in the production in relation to the agronomic characteristics.

The canonical discriminate analysis allows corroborating the analysis of principal components above, and 
Table 2. Descriptive statistics for the quantitative agronomic characteristics of the grapevine variety Quebranta province of Ica, 2011-2014.

\begin{tabular}{llllllll}
\hline Quantitative characteristics & \multicolumn{3}{c}{ Statistics } \\
\cline { 2 - 7 } & Mean & $\operatorname{Var}(\mathrm{n})$ & S.D. & S.E. & C.V. & Mín. & Máx \\
\hline Weight of grapes per strain (g/strain) & 15435.58 & 64986223.23 & 8079.62 & 542.27 & 52.34 & 1460.00 & 57470.00 \\
Number of bunches & 50.06 & 438.35 & 20.98 & 1.41 & 41.92 & 8.00 & 124.00 \\
Average bunch weight (g) & 314.48 & 4718.30 & 68.85 & 4.63 & 21.89 & 160.00 & 598.69 \\
Average weight of 100 berries (g) & 2.74 & 0.29 & 0.54 & 0.04 & 19.71 & 1.60 & 4.27 \\
Bunch length (mm) & 165.29 & 458.21 & 21.45 & 1.44 & 12.98 & 13.75 & 241.36 \\
Bunch width (mm) & 120.30 & 177.53 & 13.35 & 0.90 & 11.10 & 89.64 & 229.00 \\
Ravaz index & 7.07 & 18.19 & 4.27 & 0.29 & 60.47 & 0.94 & 23.42 \\
\hline
\end{tabular}

Table 3. Weighted average for the quantitative agronomic characteristics of the vine variety Quebranta province of Ica, 2011-2014.

\begin{tabular}{|c|c|c|c|c|c|}
\hline Strain & Bunch weight $35 \%$ & $\begin{array}{l}\text { Berries weight } \\
\mathbf{3 5 \%}\end{array}$ & Bunch length 15\% & Bunch width $15 \%$ & Weighted average \\
\hline QT1 & 166.17 & 1.19 & 28.55 & 19.11 & 215.02 \\
\hline QT5 & 159.93 & 1.07 & 27.55 & 18.78 & 207.33 \\
\hline QCH2 & 151.78 & 1.05 & 28.25 & 18.83 & 199.91 \\
\hline QCH3 & 105.51 & 0.95 & 27.16 & 17.54 & 205.57 \\
\hline QYJ1 & 145.99 & 1.13 & 26.99 & 20.02 & 194.13 \\
\hline QT2 & 138.99 & 1.13 & 27.42 & 19.44 & 186.98 \\
\hline QT3 & 139.13 & 0.98 & 26.71 & 20.07 & 186.90 \\
\hline QYJ4 & 138.62 & 1.13 & 26.48 & 20.06 & 186.29 \\
\hline QT4 & 134.80 & 1.03 & 25.93 & 20.29 & 182.04 \\
\hline QCH1 & 150.37 & 1.05 & 27.92 & 19.37 & 179.34 \\
\hline QSA3 & 129.72 & 0.95 & 28.04 & 18.94 & 177.65 \\
\hline QM2 & 131.82 & 1.03 & 25.15 & 19.11 & 177.11 \\
\hline QSA4 & 128.26 & 0.90 & 28.44 & 18.79 & 176.38 \\
\hline QST1 & 129.26 & 0.85 & 26.85 & 18.62 & 175.57 \\
\hline QG2 & 121.73 & 1.21 & 25.75 & 26.03 & 174.73 \\
\hline QG5 & 124.46 & 1.16 & 26.63 & 18.78 & 171.03 \\
\hline QCH5 & 125.13 & 1.14 & 25.46 & 17.55 & 169.28 \\
\hline QCH4 & 120.59 & 1.05 & 27.66 & 18.62 & 167.91 \\
\hline QG1 & 120.78 & 1.06 & 26.34 & 18.87 & 167.06 \\
\hline QYJ5 & 121.22 & 0.97 & 26.20 & 18.63 & 167.02 \\
\hline
\end{tabular}

Selected the 20 best strains.

determining the characteristics discriminates. The variable number of clusters per vine is the most important to discriminate the 77 strains of vine Quebranta, with the highest positive value (0.63) on the shaft. However the axis 2 shows two important variables of bunch length and weight of berry with a value of (0.58) indicating that they are the most important variables to discriminate among the 77 strains of Quebranta grapevine.

\section{Discussion}

The five best strains are QT1, QT5, QCH3, QCH2 and $\mathrm{QYJ} 1$, are found in the vineyards located on Tres Esquinas,
Cachiche and Yajasi LC. The weighted average fluctuates in $215.02,207.33,205.57,199.91$ and 194.00 respectively. In the descriptive statistics, it is noted that the lower variability is given for the variable width and length of bunch, average weight of berry and bunch. The bunches of the variety Quebranta weigh on average $314 \mathrm{~g}$, measuring $165 \mathrm{~mm}$ in length and $120 \mathrm{~mm}$ wide. The berry weighs on average $2.74 \mathrm{~g}$. The weight variables grape per vine and number of bunches of Ravaz index had greater variability compared with the other agronomic variables considered.

With respect to the parameter composition of grapes (soluble solids, total acidity and $\mathrm{pH}$ ) there are significant differences to the grapes from Quilloay, Yajasi MR and 
Table 4. Multivariate analysis for soluble solids, acidity, $\mathrm{pH}$ of the vine variety Quebranta province of Ica, 2011-2014.

\begin{tabular}{|c|c|c|c|c|c|c|c|}
\hline $\begin{array}{l}\text { Location of } \\
\text { vineyards }\end{array}$ & $\begin{array}{l}\text { Soluble } \\
\text { solids ( }{ }^{\circ} \text { Brix) }\end{array}$ & $\begin{array}{l}\text { Total } \\
\text { acidity }(\mathrm{g} / \mathrm{L})\end{array}$ & pH & & & & \\
\hline Quilloay & 23.60 & 3.98 & 3.55 & A & & & \\
\hline YajasiMR & 23.75 & 4.37 & 3.73 & A & & & \\
\hline Huaranga & 24.43 & 3.78 & 3.71 & A & & & \\
\hline Yanquiza & 26.60 & 4.23 & 4.00 & & B & $\mathrm{C}$ & $\mathrm{D}$ \\
\hline Puno & 25.56 & 3.89 & 4.00 & & B & $\mathrm{C}$ & \\
\hline Longar & 24.92 & 3.30 & 4.00 & & B & & \\
\hline Conuca & 25.24 & 3.17 & 4.00 & & B & & \\
\hline TresGeneraciones & 24.04 & 4.13 & 4.00 & & & $\mathrm{C}$ & $\mathrm{D}$ \\
\hline Macacona & 23.56 & 4.24 & 4.00 & & & $\mathrm{C}$ & $\mathrm{D}$ \\
\hline Cachiche & 25.50 & 4.51 & 4.00 & & & $\mathrm{C}$ & $\mathrm{D}$ \\
\hline Los Pobres & 23.23 & 4.05 & 4.00 & & & $\mathrm{C}$ & \\
\hline San Antonio & 26.20 & 4.55 & 4.00 & & & & $\mathrm{D}$ \\
\hline Huarango mocho & 23.92 & 4.78 & 3.90 & & & & $\mathrm{D}$ \\
\hline YajasiLC & 24.78 & 4.97 & 4.00 & & & & $\mathrm{D}$ \\
\hline
\end{tabular}

Means with the same letter are not significantly different $(\mathrm{p}>0.05)$.

Table 5. Average number of each day of phenological stage for the 77 strains of the variety of Quebranta province of Ica, 2011-2014.

\begin{tabular}{lllllll}
\hline $\begin{array}{l}\text { Stages } \\
\text { phenological }\end{array}$ & $\begin{array}{l}\text { Pruning to } \\
\text { green tip }\end{array}$ & $\begin{array}{l}\text { Green tip to } \\
\text { flowering }\end{array}$ & $\begin{array}{l}\text { Full flowering } \\
\text { to full veraison }\end{array}$ & $\begin{array}{l}\text { Full veraison to } \\
\text { maturity }\end{array}$ & $\begin{array}{l}\text { Total } \\
\text { phenological } \\
\text { cycle }\end{array}$ \\
\hline 77 strain (day) & 32.75 & 44.38 & 71.26 & 53.25 & 201.64 & $\mathrm{a}$ \\
\hline
\end{tabular}

Table 6. Multivariate analysis for the quantitative agronomic characteristics of the vine variety Quebranta province of Ica, 2011-2014.

\begin{tabular}{|c|c|c|c|c|c|c|c|c|c|c|}
\hline $\begin{array}{l}\text { Agronomic } \\
\text { group }\end{array}$ & $\begin{array}{l}\text { Bunch } \\
\text { weight }\end{array}$ & $\begin{array}{l}\text { Grape } \\
\text { weight/ } \\
\text { strain }\end{array}$ & $\begin{array}{l}\text { No. of } \\
\text { bunch/ } \\
\text { strain }\end{array}$ & $\begin{array}{l}\text { Berry } \\
\text { weight }\end{array}$ & $\begin{array}{l}\text { Bunch } \\
\text { length }\end{array}$ & $\begin{array}{l}\text { Bunch } \\
\text { width }\end{array}$ & $\begin{array}{l}\text { Ravaz } \\
\text { index }\end{array}$ & & & \\
\hline Group 2-3 & 300.64 & 14466.94 & 56.26 & 2.41 & 155.05 & 115.27 & 9.94 & A & & \\
\hline Group 2-2 & 297.58 & 13523.56 & 45.21 & 2.78 & 167.24 & 119.04 & 5.14 & & B & \\
\hline Group 2-1 & 199.06 & 2835.00 & 15.00 & 2.51 & 85.74 & 115.25 & 5.46 & & & $\mathrm{C}$ \\
\hline Group 1 & 385.67 & 23139.07 & 60.12 & 2.99 & 177.37 & 130.36 & 9.89 & & & D \\
\hline
\end{tabular}

Means with a common letter are not significantly different $(p>0.05)$.

Huaranga. The ${ }^{\circ}$ Brix fluctuates between $23.60 \%$ to 24.43 ; the total acidity between 3.78 to $4.37 \mathrm{~g} / \mathrm{L}$ tartaric acid and the $\mathrm{pH}$ between 3.55 to 3.73. The grapes of Longar and Conuca, ${ }^{\circ}$ Brix fluctuates between 24.92 and 25.24 ; the total acidity between 3.17 and $3.30 \mathrm{~g} / \mathrm{L}$ tartaric acid and the $\mathrm{pH}$ is 4.00. The grapes of San Antonio, Huarango Mocho y Yajasi LC, the ${ }^{\circ}$ Brix fluctuates between 23.92 and 26.20, the total acidity between 4.55 and $4.97 \mathrm{~g} / \mathrm{L}$ tartaric acid and $\mathrm{pH}$ between 3.90 and 4.00. The five best strains are found in the vineyards located on Tres Generaciones and Cachiche, where the ${ }^{\circ}$ Brix fluctuates between 24.04 and 25.50, total acidity between 4.13 and $4.51 \mathrm{~g} / \mathrm{L}$ tartaric acid, $\mathrm{pH}$ is 4.00 .

The phenological period not present significant differences for the 77 strains. From pruning to From green tip 33 days, from green tip to flowering 44 days, of full flowering at veraison 71 full days, full veraison to maturing 53 days and all the phenological period was 201 days. There was no presence of Grapevine virus fanleaf virus, Grapevine fleck virus, Grapevine leafroll virus 1 Grapevine leafroll virus 3 and Tomato ringspot virus in the 77 strains studied.

The conglomerate analysis and multivariate variance it allowed observe that strains are grouped into two groups. The second group has three subgroups in turn. The grouping of vineyards are not given exactly for the location the vineyard respect to the location in the province of Ica, but strains reached the best weighted average. Much so that the vineyards grouped in the first group (17 strains), are characterized by being located in up town and low prevalent strains with the best weighted average QT, QYJ and 


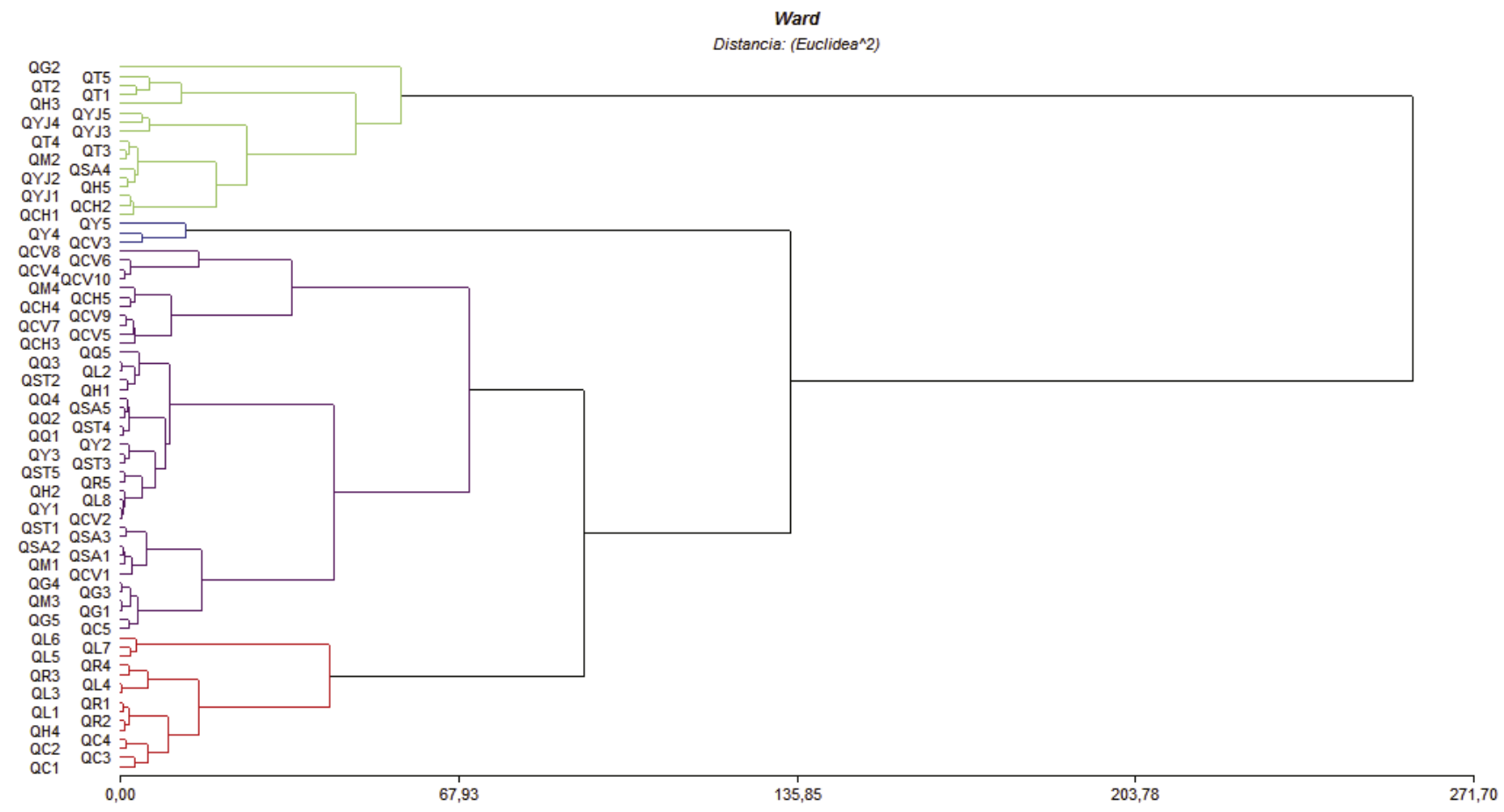

Figure 2. Dendogram of agronomic classification of 77 strains vine Quebranta.

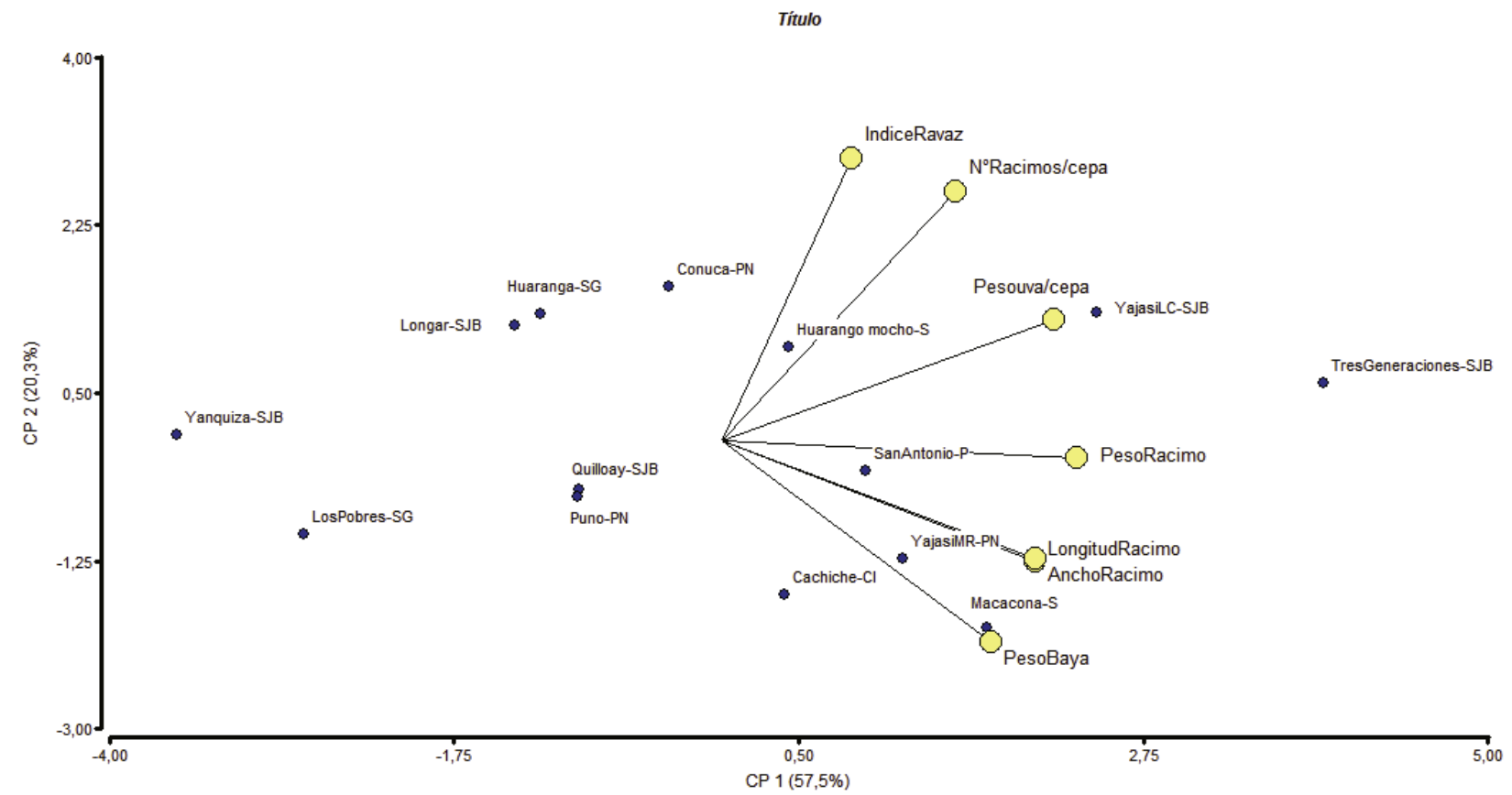

Figure 3. Biplot Graph, main components of the quantitative traits and their relationship to the places where grapevines are grown Quebranta province Ica, 2011-2014.

QCH. Soil texture vineyard is characterized by sandy loam with $\mathrm{pH} 7$ and $\mathrm{CE} 0.9$. The second group (60 strains) and specifically in subgroup 1 are the strains with lower weighted average QY and QCV, located in uptown. Soil texture vineyard is characterized by sandy loam with $\mathrm{pH}$ 7.5 and CE $2.02 \mathrm{dS} / \mathrm{m}$.
There aren't others studies where have been characterized the variety Quebranta, therefore we compared with a table grape variety well known Red Globe, that on average bunch weight $559 \mathrm{~g}$ and $9.42 \mathrm{~g}$ berry [10].

The high variability observed for grape weight per strain, number bunches and Ravax index, this is due to the 
high modification of the conduction system "Galera from Ica" in each of the vineyards evaluated with many arms and pythons. The Ravaz index must be between 4 and 9 . Above these values is considered that there may be a risk from overwork harvest [8].

In CITEagroindustrial, to carry out the fermentation process of the musts for making Pisco, this must be within the range of ${ }^{\circ}$ Brix $22-26$, acidity $3.5-7.0 \mathrm{~g} / \mathrm{L}$ tartaric acid and $\mathrm{pH}$ between 3.2 and 3.7. The 77 strains are within the ranges for ${ }^{\circ}$ Brix and total acidity but they exceed the threshold of $\mathrm{pH}$ in the majority of strains. Bear in mind that when you exceed the $26^{\circ} \mathrm{Brix}$, it is lost grape aromas and starts a process of dehydration with less acidity as notes in the grape evaluated in San Antonio (4.55 g/L tartaric acid). Quebranta is called a non-aromatic variety [11] in comparison with Muscat of Alexandria (called in Peru, "Italy") [1].

The phenological period of this variety can be compared with other that are cultivated in Ica. Table Grapes Red Globe (total 190 days) and Thompson Seedless (total 176 days) and Syrah wine varieties (total 193 days) and Sauvignon blanc (total 168 days). The variety Quebranta has the longest phenological cycle because it is considered maturation when it fluctuates between $24-26^{\circ}$ Brix unlike other varieties of table and wine are harvested at 16 and $22{ }^{\circ}$ Brix, respectively (unpublished data).

About healing, it isn't excluded that strains susceptible to infection for other asymptomatic virus affecting the grapevine and present in Ica (results not shown).

The strains with less weighted average are found in soils with high salinity. In this regard the grapevine is little tolerance to salinity $(\mathrm{EC}<2-3 \mathrm{dS} / \mathrm{m})$ as to overcome the high osmotic potential that produce salts in the soil, the plant should increase their respiratory activity getting the energy needed; causing a decrease in force, adversely affecting the biomass of stem, and leaves thumbs and fertility of the buds, accompanied by a reduced harvest. And also the effects of high $\mathrm{pH}$ cause low availability (shortages) of the elements phosphorus, manganese, boron, copper and zinc. Increases availability (toxicity) of the elements molybdenum, sulfur and calcium. Modifying the structural stability of the soil by flocculation of clays [12].

The strains chosen are an alternative for the production of grapevine Quebranta in the agroclimatic conditions of Ica in virtue of the performance advantages and agronomic characteristics, therefore it is suggested your validation agronomic. The parameter of grape composition is within the thresholds with which the CITEagroindustrial (Quilloay, YajasiMR y huaranga), therefore it is suggested your validation agronomic of this strains.

The vineyards study are located in the zone high, medium, and low in the province of Ica, each one of them was independently managed, it is known that is carried out by each producer, do not receive direct advice of specialized professionals, only by the knowledge acquired in training specific. It performs a basic NPK fertilization and guano. Pests are treated with sulfur until that the bunch is in pea size, and then in some cases apply synthetic fungicides. The time of pruning is important and is performed in the majority of vineyards when the moon is in the full moon phase. Usually the "galleries" are located around the lots, where there is an irrigation ditch and such have good moisture. These plants have more than 15 years of installed and in only a vineyard are appreciation fungi of wood where it was observed that the weighted average was one of the lowest QY5. Other tasks are very similar in all the vineyards.

Entirely strains are free; you are expected to know the agronomic performance when they are grafted a pattern that to be drought tolerant or phylloxera and strains are grown in a same microclimate and are brought to the same cultural and agronomic management.

\section{Conclusion}

The best five strains are QT1, QT5, QCH3, QCH2 and QYJ1, are found in vineyards Tres Esquinas, Cachiche and YajasiLC. This strains will serve to start plans mass propagation and for further research.

Is appreciated at support professionals CITEagroindustrial in executing the various research activities. A Manuel Morón, Juan Carlos Zamora by budget allocation for the implementation of research. The owners of vineyards by allow conduct assessments: Mirtha Alvarez, Hugo Quijandria, José Carlos Falconi, Pedro Alva, Carlos Ruiz, Julio Sotelo, Pilar Gonzales, César Falla, Marlene Ramos, Luz Carhuayo, Carmen Pariona, Rosario Garcia and Olinda Lovera.

\section{References}

[1] OIV (International Organization of Vine and Wine). 2013. List of varieties.

[2] O. Soarez. Peruvian Pisco and wine cellars. First edition. 137 pages (2008)

[3] L. Huertas. History of the production of wine and pisco in Peru. Universum Magazine 2 No. 19: 44-61 (2004)

[4] Standard Technical Peruvian 211.001 Alcoholic Beverages. Pisco. INDECOPI, Lima, Peru, 2006.

[5] L. Lacoste. The grapevine and wine in South America: the displacement of wine poles (XVI to XX) Universum Magazine 2 No. 19: 62-93 (2004)

[6] CEPES PE. 2015. Notiagro. Ica has viníferes 6000 acres of grapes and pisco (online). Peru.

[7] G. Orjeda, Molecular analysis of pisco grapes. Lima. Universidad Peruana Cayetano Heredia (interview) Peru (2008)

[8] S. Garcia. Description, health and agronomic characterization of the red variety Rufete in the Sierra de France (Salamanca). Work entitled, Department of Agricultural and Forest Engineering. University of Valladolid - Spain (2005)

[9] J. Perez, J. D. Prehm, A. Soto. Health and clonal selection. The timing of the Moscatel Rosada. Agronomy and Forestry No. 42. Chile (2011)

[10] B. Pugliese. Influence of leaf removal and trim in color development and other variables of quality in the cultivar Red Globe under hail mesh. Thesis Mag. Sc. San Juan de Cuyo, AR. National University of Cuyo (2009)

[11] Regulatory Board of Pisco. Regulation of the Designation of Origin Pisco. Peru (2012).

[12] L. Hidalgo, J. Hidalgo. Treaty of viticulture. Fourth edition. Mexico. Oxford University Press. 1 (2011) 